\title{
Still standing
}

\section{On the use of dioramas and mannequins in Sámi exhibitions}

\author{
Silje Opdahl Mathisen
}

\begin{abstract}
This article is about the use of dioramas in Sámi exhibitions. The author discusses the use of a specific exhibition technique where a mannequin and a taxidermied reindeer are grouped together, and often placed in an illusionary winter landscape. She has named this the Lappish Equipage. This form of representation has a long history both inside and outside museums, and it can be found in both Sámi and ethnic Norwegian and Swedish museums. The author discusses how this diorama works, and how its chequered past through appearances in various types of exhibitions makes it problematic to use in contemporary museum exhibitions about the Sámi. On the other hand, the author also points out that if the Lappish Equipage is re-framed and re-contextualized, and its exhibition history is consciously activated, the Lappish Equipage has a potential to work as a contact point between Sámi history and visitors in the museums today.
\end{abstract}

Keywords: Dioramas, mannequins, taxidermy, representations of the Sámi, indigenous museums.

Different types of bodily representations are present in exhibitions at museums of cultural history and ethnography. It can be bodies in human form, in the shape of drawings, photographs, dolls or mannequins, or in non-human, animal form, often as taxidermied animals. This article examines how bodies of humans and animals are used in Sámi exhibitions in Norway and Sweden today. ${ }^{1}$ Mannequins, taxidermied animals and dioramas are a prominent feature in many of these exhibitions. ${ }^{2}$

Representations of Sámi culture and history have been present in exhibitions at venues as various as world fairs, zoos, museums of ethnography and museums of cultural history, and, for the past thirty years or so, in Sámi museums. ${ }^{3}$ Today, Sámi exhibitions can be found in both Sámi museums and majority museums. A recurring motifin these exhibitions is what I call the Lappish Equipage. ${ }^{4}$ This is a representation that consists of a mannequin wearing a traditional Sámi costume, placed together with a life-like stuffed reindeer. The reindeer can often be seen pulling a sledge, and the whole scene can be surrounded by an illusionary winter landscape. Over time, this has become an almost iconic depiction of Sámi culture. Below, I will look at how this motif is used in museums today. In discussing how and 


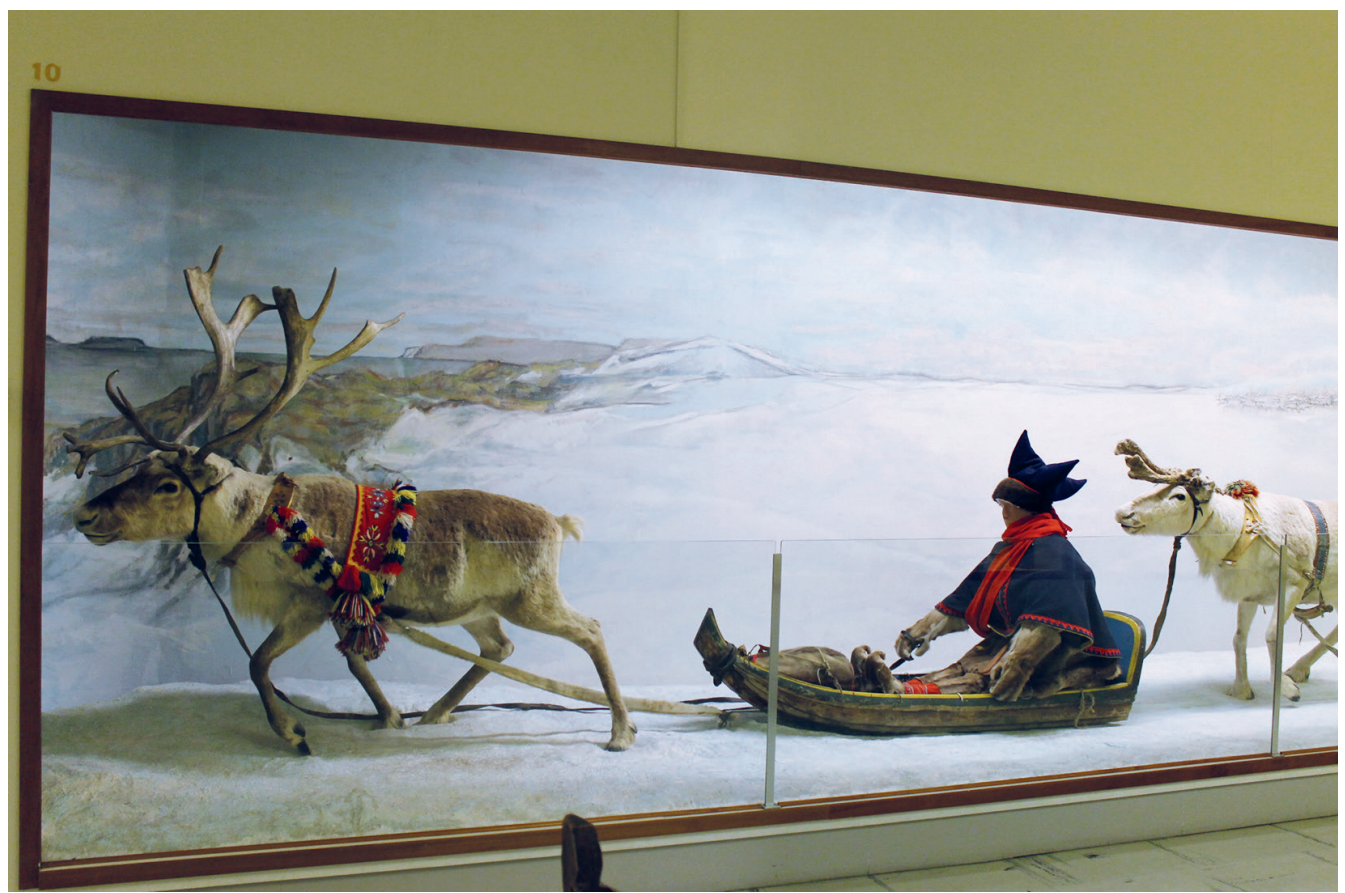

Fig. 1. From the exhibition Samekulturen (The Sami Culture) which opened in 1973 at Tromsø Museum Universitetsmuseet. Photo: Silje Opdahl Mathisen.

why this diorama is so widely used in Sámi exhibitions, I will also discuss how a diorama like the Lappish Equipage works, and how it might be used in the future.

This article is based on a material collected from fourteen Sámi exhibitions in six museums in Norway and Sweden over a period of five years. I visited two Sámi museums in Norway: RDM-Sámiid Vuorká-Dávvirat (De Samiske Samlinger) in Karasjok and Várjjat Sámi Musea (Varanger Samiske Museum) in Varanger, and one Sámi museum in Sweden: Ájtte Museum in Jokkmokk. In addition I also visited majority museums with exhibitions dedicated to Sámi history at Norsk Folkemuseum in Oslo and Tromsø Museum - Universitetsmuseet in Norway, and Nordiska Museet in Stockholm,
Sweden. My analysis is based on notes, photos and observations I did during my visits and on interviews with museum staff and reviews of the exhibitions in the press.

In some exhibitions, the Lappish Equipage is still standing but in other exhibitions it has been replaced by other forms of representations of the human body. This article examines the ways the body is staged in the exhibitions and I will argue that in the so-called majority museums, the three-dimensional Lappish Equipage is being replaced by two-dimensional photos, and that this change relates to a shift from a timeless, de-personalized representation of the Sámi as a type or a specimen, to a representation of Sámi identity through individual, portraitlike photos with an emphasis on the present. 


\section{EXHibitions OF SÁMI CULTURE}

During the past half century the Sámi have experienced an ethno-political awakening. Parallel to the Sámi political movement there has also been a revitalization of Sámi culture (Eidheim 1997; Stordahl 2000). The right to self-representation has been an important part of the ethno-political struggle. Several Sámigoverned museums have been created since the 1970s across Sápmi: in Norway, Sweden, Finland and Russia (see for example Amundsen 2011; Pareli et al. 2012). The emergence of the first Sámi museums can be seen as a reaction to the stereotypical way the Sámi were represented at the majority museums. Europe's representation of other cultures has been the subject of critical debate since the end of the 1970s. European museums contributed to a stereotypical view of other cultures, including the Sámi, where conceptions of race, mentality and culture were essentialized, and this ultimately served to legitimize Western hegemony. Over approximately the last thirty years there has been an increase in the cultural, social and economic rights of indigenous people. The development of the Alta-Kautokeino hydroelectric power plant in Northern Norway and the protests against this development in the 1970s and beginning of the 1980s was a turning point in the Sámi ethnopolitical movement. The creation of a number of Sámi museums since the 1970s can be seen in relation to such ethno-political processes, together with an emergence of new theoretical frameworks for understanding ethnicity and cultural variation within the disciplines of anthropology and sociology. These changes must also be seen in connection with the emergence of post-colonial theory and its emphasis on the cultural and political rights of minorities.

The Sámi museums were created out of a need to preserve the Sámi heritage, to make Sámi culture more visible, and to strengthen Sámi identity. Since the 1970s, the Sámi museums have played an important role in creating and strengthening Sami identity.

There is a growing body of museological research on Sámi museums. Some have criticized the exhibitions at the Sámi museums for being very much like the older exhibitions of Sámi culture at the majority museums in Scandinavia, and for showing a timeless and static picture of Sámi culture (Olsen 2000; Mathisen, S.R. 2004). This critique also points out that in so doing the Sámi museums are in danger of reproducing old ethnographic stereotypes. Partly, the reason for this critique can be found in the paradox that Sámi museums use some of the same "icons" or material representations that were used in the older exhibitions of Sámi culture at the various majority museums. The representation I call the Lappish Equipage seems to have an especially long life. The Lappish Equipage is not only a thing of the past. It still stands in several museum exhibitions today, as well as in several exhibitions outside the museum world.

The equipage has, of course, its origin in Sápmi and how it was used in everyday life by Sámi reindeer herders. In this article, I focus on how the equipage has been used to symbolize what is Sámi, and what this "Sámi" entails. This means that I look chiefly at versions of the equipage made and used by someone other than the Sámi themselves, in exhibitions inside and outside museums. In these, the Lappish Equipage has been part of a broader discourse about human evolution. Over time, the Lappish Equipage has travelled through several changing master narratives, from the conception of the Sámi as the original inhabitants of the North and a "noble savage", through a period where the Sámi were seen 


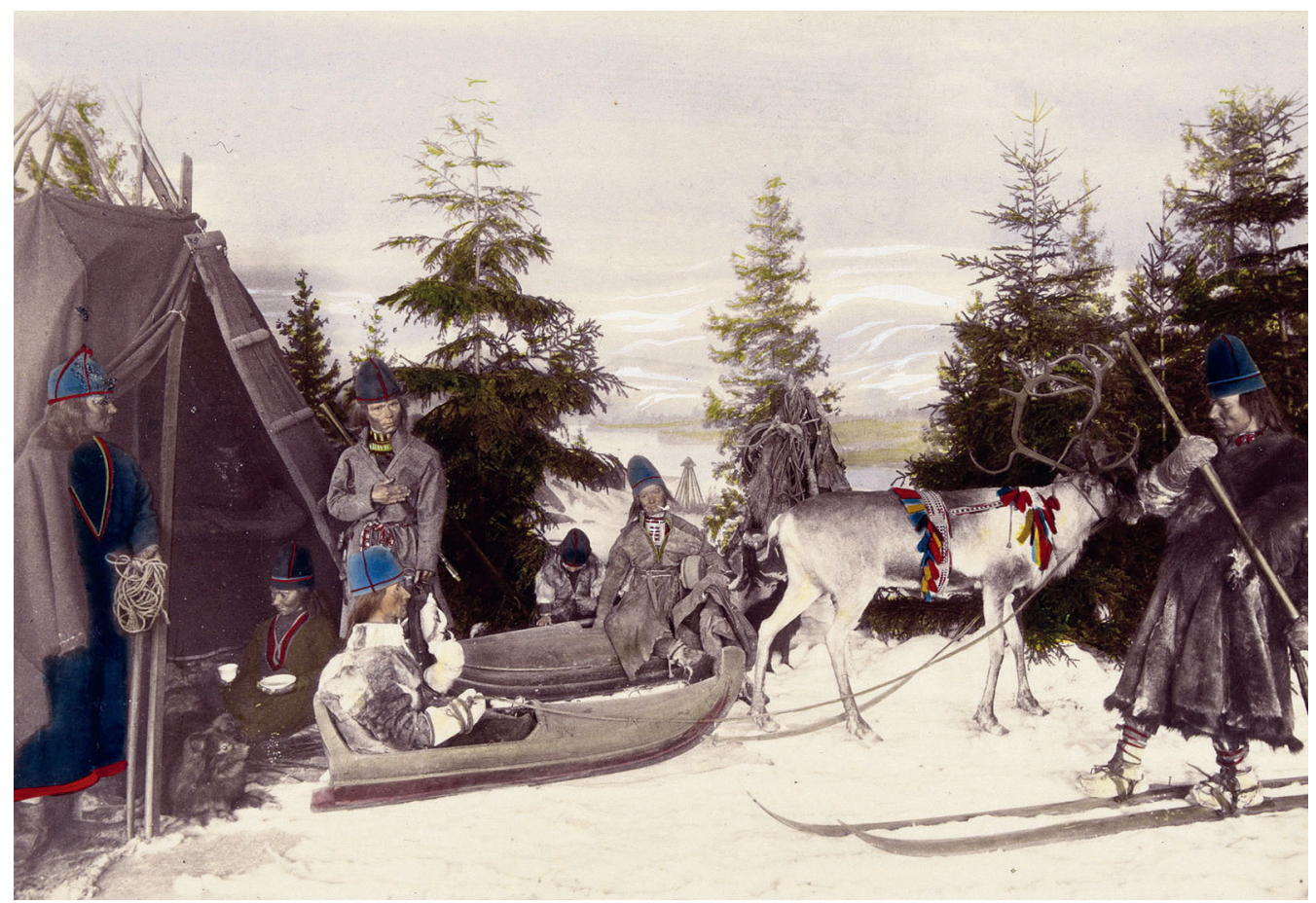

Fig. 2. From the exhibition at Skandinavisk-Etnografiska samlingen, later Nordiska Museet, in Stockholm. This exhibition opened in 1873. Photo: Axel Lindahl 1874.

as belonging to a primitive and inferior race that had immigrated from the East, and up till today when the Sámi and other indigenous peoples are seen as equal, although with some special rights connected to their indigeneity (though these rights are a source of constant debates).

The Lappish Equipage has a long history, both inside and outside of the museum, both as a two-dimensional image and as a threedimensional diorama. The Swedish researchers Leif Lindin and Ingvar Svanberg have examined the origins and distribution of this image (Lindin \& Svanberg 1990). They trace the oldest version of this image back to the sixteenth century and Olaus Magnus' famous map Carta Marina, dated 1539. The same motif is repeated in Olaus Magnus' The History of the Nordic People, published in 1555. Lindin and Svanberg reckon that it was Johannes Schefferus' Lapponia (1673) that made the image of the Lappish Equipage well known and contributed to its broad circulation. Schefferus' version of the Lappish Equipage was used in a wide range of publications in Europe in the seventeenth and eighteenth centuries. Among these was Carl Linnaeus' Flora Lapponica (1737), where the Lappish Equipage was used on the flyleaf. According to Lindin and Svanberg, Schefferus' Lapponia was distributed widely and internationally, and this contributed to giving Schefferus' version of the 
Lappish Equipage a dominant role in the Sámi iconography (Lindin \& Svanberg 1990:113118).

Although it cannot be called a diorama, the earliest three-dimensional version of the Lappish Equipage in a museum context can be traced back to 1694, when King Carl XI of Sweden received a gift in the form of a "stuffed" reindeer pulling a sledge (NodermannHedqvist \& Manker 1971). The reindeer was made of a wooden core covered in reindeer skin. The sledge was an authentic pulk (Sámi sledge). A mannequin dressed in authentic Sámi clothes was sitting in the sledge, with a runebomme (Sámi shaman drum) in its lap. This version of the Lappish Equipage was exhibited in the Royal Armoury museum (Livrustkammaren) in Stockholm and even though this particular equipage is no longer exhibited the museum still retains many of its original parts (Mathisen, S.O. 2014:209). In the same article, Nodermann-Hedqvist and Manker note that King Carl XI had an interest in exotic animals. This was an interest he shared with other European nobility at the time. Gunnar Broberg, Swedish researcher in the history of ideas, refers to several written sources about how reindeer were showcased in the European courts at the time, often accompanied by Sámi to take care of the reindeer (Broberg 1982:28-29). Broberg makes a point of how, in the nineteenth century, the interest in these displays shifted from the reindeer to the Sámi themselves (Broberg 1982:28). The end of the nineteenth and the beginning of the twentieth century was the heyday of the "live exhibitions", where people from other cultures were shown at various venues such as world fairs and zoos. Many of these exhibitions were about the Sámi. These exhibitions were fairly standardized, and the Lappish Equipage was a predominant element.
The Norwegian archaeologist Cathrine Baglo sees these exhibitions as a visual technology which was given meaning by and at the same time gave meaning to a particular view of human cultures and races. Abstract categories such as evolution, prehistory, biology and race were visualized and materialized through these exhibitions (Baglo 2006, 2011).

Mr. Bullock's Exhibition of Laplanders at the Egyptian Hall in London in 1822 is an early example of a live exhibition, where a Sámi family from Røros in Norway performed with authentic reindeer (Mathisen, S.R. 2007; Pearce 2008; Andersson Burnett 2013). Mr. Bullock was influenced by Carl Linnaeus and portrayed the Sámi family from Røros as peaceful children of nature. The Swedish researcher in the history of ideas Linda Andersson Burnett compares Mr. Bullock's exhibition and advertising with the reception the exhibition got in the press at that time, and she sees an ambiguity in how the audience and the press experienced it (Andersson Burnett 2013). While the press partly accepted Mr. Bullock's version of the Sámi family as the noble savage and children of nature to be admired and from whom the British "civilized" audiences could learn a thing or two, there were also a growing choir of voices that saw the Sámi family in this exhibition as belonging to another and inferior race. According to Andersson Burnett, Mr. Bullock's exhibition of Laplanders "illustrates the demotion of the trope 'noble Savage' to that of a mere savage during the 1820s" (Andersson Burnett 2013:190).

Cathrine Baglo has examined the Sami participation in live exhibitions. Performing with reindeer and sledge was a central part of these exhibitions. According to Baglo, the museums adapted this way of portraying the Sami from the live exhibitions, with some important adjustments. The museums 
replaced live people with mannequins, and living reindeer with stuffed animals (Baglo 2011). The Lappish Equipage was present in some of the earliest museum exhibitions in both Oslo and Stockholm: in Stockholm at the Nordic Museum (Nordiska Museet, then called Skandinavisk-etnografiska samlingen), and in Oslo at the Ethnographic Museum (Mathisen, S.O. 2014:214-217). Even though the background for the first exhibitions of Sámi culture at the majority museums is different in Norway and Sweden, and even though these exhibitions took place in different types of museums, they still show a remarkable likeness. Centrally staged in all the exhibitions about Sámi culture we find the Lappish Equipage. This material representation shows a remarkable persistence in time and space, and can be found in both majority museums and in some of the later Sámi museums. Whilst some of the material representations of Sámi culture remain much the same at both majority museums and Sámi museums, the significance of this representation changes as the context and narrative change.

At the Sámi museums, the Lappish Equipage has been a part of a discourse concerning Sámi identity and ethno-politics. As mentioned, the first Sámi museums were criticized for relying on the same material expressions as the majority museums. But these material expressions can here be interpreted as an attempt to rebuild and reinforce Sámi identity. The Sámi museums were trying to strengthen Sámi cultural identity by focusing on objects and traits that set it apart from the majority culture. This approach can be seen as a kind of strategic essentialism (Hodgson 2002:1040). The Sámi museums have thus played an active role in negotiating and creating what is perceived as essentially Sámi. From a postcolonial perspective, the Lappish Equipage at the Sámi museums can be seen as a moment of confrontation, whereby the Scandinavian discourse is being challenged because "the Other" that previously has been represented as an object now acts as the subject and is answering back.

\section{The LAPPISH EQUipage as AN EXHIBITION TECHNIQUE}

The Lappish Equipage is a form of museum display that is usually composed of three parts: one part is realist taxidermy in the form of a reindeer, the second part is a mannequin, usually a man, dressed in a traditional Sámi costume, and the third part of the display is the surroundings or the stage that the mannequin and the reindeer are placed on. This often takes the form of a winter scene. One could add a fourth part to this scheme, which actually was the reason for the whole display, and that is the objects on display. In the museum, the Lappish Equipage is a device to show off or present authentic objects like the harness, the sledge and the traditional costume. The first three parts - the reindeer, the mannequin and the surroundings - can be seen as props or contextualization tools to show off the authentic objects. This form of representation was part of a new development in museums of the late nineteenth century, where taxonomic display principles were rejected in favour of living, contextualized scenes. To quote the American media historian Mark Sandberg: "it is a compensatory mise-en-scène that gave displaced objects and bodies a new kind of scenic home" (Sandberg 2003:8).

The Lappish Equipage is a form of exhibition technique that is often referred to as a diorama. A diorama is a model representing a scene with three-dimensional figures, either in miniature or as a large-scale museum exhibit (Oxford 
Dictionary). Dioramas became popular in the early stages of the nineteenth century as a new theatrical form of visual art, patented by J. L. M. Daguerre in 1822. Such dioramas, like their predecessors the panorama, became a popular entertainment throughout Europe until photography proliferated in the mid-1880s. The word "diorama" virtually disappeared until the 1930s and the 1940s when it was applied in natural history museums habitat displays (Wonders 1993). As defined in a museum setting, a diorama is "a display consisting of a constructed foreground with fabricated or preserved elements (plants, rocks, water etc.) and (usually) stuffed (or modelled) fauna. The constructed foreground is blended seamlessly into a realistically painted background, which then extends the vision to the horizon" (Whitson 1996:202). Today, "diorama" is a multi-purpose label for a variety of simulated environments, either life-size or in miniature.

During the same period the diorama evolved, taxidermy techniques were developed almost into an art form. Taxidermy is the art of mounting or reproducing dead animals for display or study. According to American feminist theorist Donna Haraway, taxidermy became the art most suited to the epistemological and aesthetic stance of realism. The power of this stance is its magical effects: what appears so effortlessly, spontaneously found, or discovered, is actually painfully constructed (Haraway 1985).

The Lappish Equipage belongs to a category of dioramas that are realistic and life-size museum displays. This kind of museum display can again be divided in two main categories, depending on whether they display animals or humans. Dioramas containing stuffed animals are usually found in displays of natural history, and are also called habitat groups or habitat dioramas. According to the German historian of science Karen Wonders, a habitat diorama is a natural history scenario which typically contains mounted zoological specimens arranged in a foreground that replicates their native surroundings in the wild (Wonders 1993:9). Dioramas with human subjects can also be called life groups. A life group diorama is an arrangement of costumed mannequins, often arranged in a dramatic tableau. Life group dioramas are (or were) usually found in displays of anthropology, and to some extent in displays of cultural history.

The Lappish Equipage is a diorama but it is hard to classify as either a habitat group or a life group. The Lappish Equipage places itself somewhere in the middle: between the habitat group and the life group, between nature and culture. It consists of nature in the form of a life-like stuffed reindeer, and culture in the form of authentic objects like the sledge and the harness and of the costumed mannequin. The Lappish Equipage is both nature and culture: it is an anthropologic-zoological representation, and it links Sámi culture to nature.

In natural history museums the diorama combines illusionistic background paintings with lifelike stuffed animals. The diorama appeals to emotions. The earliest dioramas at the natural history museums in Sweden expressed a connection between wilderness and national identity. By appealing to emotions and by the combination of extreme illusionism and romantic symbolism, the diorama produced a sense that the cultural meanings attached to nature are innate, meanings that are felt rather than read (Henning 2006:51).

\section{THE BODY PROBLEM}

The Lappish Equipage is also a body, or actually two bodies: the Sámi and the reindeer, one human and one animal. I will focus on the 
human body in the form of the mannequin in this article and from now on, when I refer to "the body", I refer to the mannequin: the representation of the human body.

The use of mannequins in exhibitions is an integrated part of the diorama tradition. As opposed to, for example, a sculpture of the human body, a mannequin is not the end product in itself. The mannequin is made to be dressed in clothes and/or accessories. Though not an invention from this period, mannequins in the form of lifelike wax and plaster figures proliferated from about 1880 to the time of World War I and could be found in storefront windows, at international exhibitions and in several different forms of museum displays (Sandberg 2003:4-5).

There is an uneasiness in the meeting with the Lappish Equipage. This is connected to the juxtaposition of a taxidermy animal and a mannequin representing a human body. But it also connected to the representation of the human body itself and this again is connected to what has been named "The Lost Body Problem". The American cultural anthropologist Jeffery David Feldman has addressed the problem with the lost bodies in an article where he considers what is lost by a museum paradigm that emphasizes visual display over other embodied experiences (Feldman 2006). Feldman examines a category of objects in museum exhibitions that he calls "contact points". These contact points are the results of physical contact with the body, and the subsequent removal or destruction of the body. Seen as such a contact point, the Lappish Equipage is an inherited legacy from colonialism, a legacy of material objects and materializing practices that are the products of unequal encounters between colonizers and colonized. Feldman criticizes the conventional museum display for not fully exploiting the potential in such contact points, for not that these contact points contain. He claims that further theorizing of these objects has the potential to make the museum visitor more open to the sensory agenda of the museum space (Feldman 2006:247).

There has been an increased interest in the body in the humanities and social sciences since the late 1970s. This renewed interest in the body stems from an acknowledgement of how fundamentally disembodied earlier social theory had been. There has been a longstanding bias against the body in Western academic tradition. This bias is usually explained as a result of a Platonic legacy and of Descartes' radical separation of mind and body and that this is some of the reasons why we today have the well-known dualisms of mind/body, reason/emotion, and objective/ subjective (Farnell 2011:136-137). What is a body and what kind of bodies do we find in the Lappish Equipage? Generally and for analytical purposes the concept of "the body" can be divided into three parts: the body as a biological organism, the body as a subjective experience, and the body as a cultural product and as an expression of a culture. The body in the Lappish Equipage is modelled on a biological organism - the human body - but it is not meant to present an individual or convey any form of subjective experience. This body, in the form of a mannequin, is a cultural product and a legacy of a colonial and racial past. Even though the face of the mannequin can have portrait-like features, it is not meant to show an individual. It is a type, a specimen. The mannequin is often dressed in a costume typical of a particular area, for example the Lule Sámi area, thus the mannequin is a representation of a typical man from the Lule Sámi area and thus it shows a particular type of Sámi. 
The human body as a type or a specimen is particularly unnerving when linked to the tradition of exhibiting live indigenous people and to the anthropometric examinations of Sámi people that were often linked to the live exhibitions (Baglo 2011). The body as a type or specimen is even more chilling when one considers the Sámi human remains that were collected and stored in public collections. In the Schreiner Collection at the Anatomical Institute, University of Oslo, there are human remains from approximately 1,000 Sámi individuals (Sellevold 2009). Since the 1970s demands have been made to repatriate these bones to their descendants and the places of origin $^{6}$

The juxtaposition of the taxidermied reindeer and the Sámi mannequin emphasizes a feeling of cultural taxidermy - the word "taxidermy" used metaphorically to describe the process of objectifying indigenous people and their objects in an a-temporal exhibition scheme like the diorama. The American art historians Mara Gladstone and Janet Catherine Berlo point out how the traditional museum representation of bodies of cultural others in the form of mannequins have "deadened" rather that enlivened the presence of this body (Gladstone \& Berlo 2011:354ff.). The concept of cultural taxidermy can be traced to Donna Haraway's seminal essay "Teddy bear patriarchy: Taxidermy in the Garden of Eden, New York City, 1908-1936", where she describes the formation of the Akeley Hall of African Mammals at the American Museum of Natural History (Haraway 1985). Haraway suggests that these dioramas do not give an exact imitation of nature, but rather present an idealized, concentrated view. Haraway suggests that Akeley's animal families reflect his generation's view of race, gender and class. In this way, dioramas tell as much about the society that created them as they do about the natural worlds they represent. Dioramas as an exhibition technology are not "neutral" nor innocent, but latent political statements.

\section{A SOLUTiOn: From THREE-DIMENSIONAL TYPES TO TWO-DIMENSIONAL INDIVIDUALS}

The Lappish Equipage is a part of Sámi history, a way to represent parts of Sámi history and, at the same time, it is also a legacy from a colonial past. At majority museums like Tromsø Museum - Universitetsmuseet and Norsk Folkemuseum in Norway, and Nordiska Museet in Sweden, the Lappish Equipage is gradually being replaced by other forms of representations of Sámi people and bodies, first and foremost by the use of contemporary portrait photography. So, the solution to "the body problem" in this case seems to be a transition from a three-dimensional diorama to two-dimensional photographs. However, this "new" way of representing bodies raises some new questions. One of these is the question of timelessness versus presentism. In the older exhibitions of Sámi culture, the Sámi were presented in an "ethnographic present", as a timeless culture, a traditional culture without possibilities for survival in a modern society. In exhibitions of Sámi culture from the 1990s and onwards at both Sámi museums and majority museums, the focus is mainly on the present. It is all about what it means to be a Sámi today, about identity. "The past" is mostly about the ethno-political struggle in the latter half of the twentieth century.

This shift in historical emphasis also reflects differences in representation versus presentation, and types versus individuals. In the "timeless" exhibitions, I found ethnographic representations of peoples and types of people. 
In exhibitions with a focus on the present, I found individual testimonies about what it means to be a Sámi today. In timeless museum representations, the Sámi are represented as "the other". In museum exhibitions with a focus on the present, the emphasis is on showing that "they" are "just like us" but with the added extra dimension of another ethnic identity.

The shift from timelessness to presentism coincides with the disappearance of the Lappish Equipage. The three-dimensional body representation in the form of mannequins disappears, and is replaced by body representations in other media such as twodimensional photographs and videos and personal testimonials that can be listened to on audiotapes. These representations give a more personalized and individual account. Sometimes these bodily representations act as witnesses, testifying to what it means to be a Sámi today or things that happened in the near past. The Lappish Equipage as an exhibition device was developed to simulate reality and was appreciated for its realistic effects. Later bodily appearances in exhibitions of Sámi culture, such as photos, videos and audiotapes, are also constructed to appear real and authentic. The witness approach gives authenticity to the stories told in the exhibitions. Cathrine Baglo describes what happened when the Lappish Equipage was moved from the live exhibitions to the museum: live Sámi were replaced with mute mannequins and museums achieved full control of the representation (Baglo 2011:300). The "witness approach" and growing awareness of the importance of making exhibitions in collaboration with Sámi groups and individuals can be seen as ways of giving the Sámi their voice back. However, this is always a voice that is framed within the confines of a museum and an exhibition.

\section{LOST IN TRANSLATION?}

According to the German-American anthropologist Franz Boas, life group dioramas were nothing more than glorified stop signs, whose aim was to direct audiences' attention to more didactic parts of the exhibition. This must obviously have worked as in 1895 he initiated the installation of no less than 28 such life group dioramas at the American Museum of Natural History (Wonders 1993:17). How do these dioramas and life groups work? What is their effect on us? And what is lost when dioramas go out of use?

The American art historian Toby Kamps has written an essay on the different uses of dioramas in modern art (Kamps 2000). According to Kamps, dioramas challenge our perceptual skills. They activate a physical response that flat images, isolated sculptures and objects cannot. They engage our sense of depth perception and, with it, a bodily awareness of space which encourages us to make the imaginary leaps into their constructs (Kamps 2000:9). The illusionistic diorama with a life-size mannequin has a certain effect; it works on us, it affects us in a way, and how this works has something to do with its three-dimensionality. The mere body and the physicality of the diorama create an intuitive response with great power which can be likened to the response to an artwork. The American researchers Mara Gladstone and Janet Catherine Berlo quote the artist Fred Wilson and how he in his art is "really interested in surprise and how one reacts on an emotional and intuitive level before the intellectual self kicks in" (Fred Wilson as quoted in Gladstone \& Berlo 2011:366). According to Gladstone and Berlo, there is a bodily moment of confrontation, the moment before the mind corrects an intuitive response. This moment is crucial and is where the artwork, or in this case the diorama, has its greatest power. 


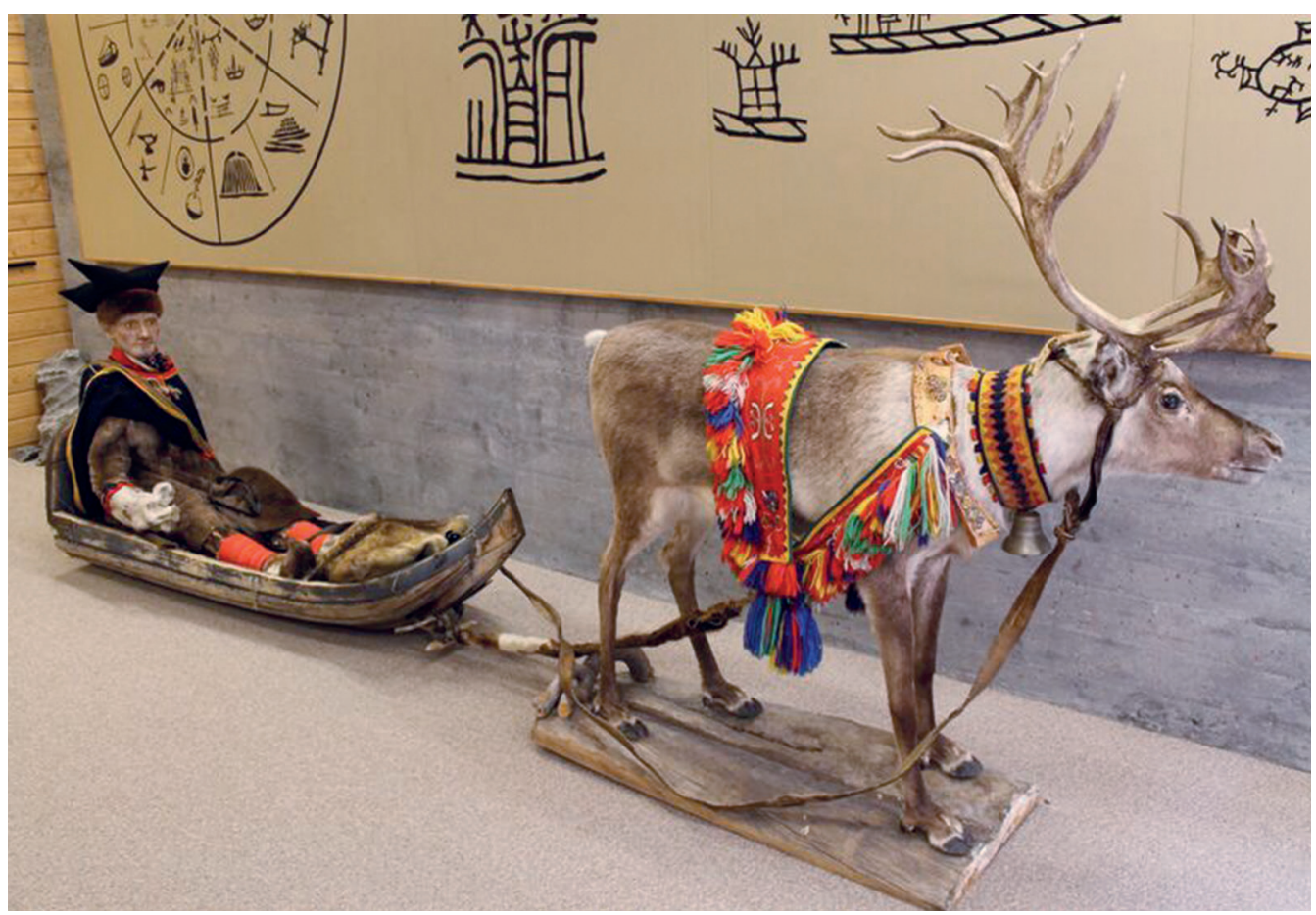

Fig 3. From the exhibition at RDM-Sámiid Vuorká-Dávvirat, Karasjok, This exhibition opened in 1986, but the Lappish Equipage is added later. Photo: Silje Opdahl Mathisen.

Dioramas like the Lappish Equipage can be likened to frozen motion pictures, like still pictures from a film. Their static nature gives an uncanny effect as human vision is keyed to motion and seeing environments and beings entirely devoid of movement is therefore disconcerting and fascinating. Dioramas simultaneously evoke life and death and create a kind of immortality (Kamps 2000:9). If the exhibition is seen as a narrative where the plot unfolds as you walk around, the Lappish Equipage and other dioramas can be seen as what the Dutch cultural theorist Mieke Bal describes as "close-ups" (Bal 2008:26-27). Such close-ups stop time and undermine the linearity of the exhibition's temporal narrative.
According to Mieke Bal, close-ups create a relationship between viewer and object that is pure affect. This affect emerges between a perception that troubles us and an action we are hesitating about (Bal 2008:35). Mieke Bal uses the concepts of "close-ups" and "affectimages" to describe objects and images that are very different from the Lappish Equipage. But still, I find these concepts useful in describing how the Lappish Equipage works. The Lappish Equipage is a stop-sign, it arrests the flow of time in the exhibition. It does not only show frozen images from the past, it also freezes the unfolding of time and narrative in the exhibition. It works on the viewer through affect, on an emotional and intuitive level, in the 
moment before the mind corrects the intuitive response. As such, the Lappish Equipage is a powerful exhibition device which works on a more affective and intuitive level than, for example, single objects and photography do. The power of an exhibition device like the Lappish Equipage unfolds in the meeting of two bodies: the body of the mannequin and the body of the spectator.

\section{STILL STANDING}

The Lappish Equipage has travelled through severaldifferent master narratives: universalistic, racist/colonialist, post-colonialist and ethnic revivalist. The Lappish Equipage is given new meaning from new contexts, but at the same time it also carries with it meaning from older contexts. The Lappish Equipage relates to a traditional Sámi way of life but it also refers to descriptions of the Sámi by early ethnographers and to exhibitions in national museums of ethnography and cultural history from the nineteenth and early twentieth century. It is therefore not unproblematic to use the Lappish Equipage in modern museum exhibitions. Indeed, from the 1990s, the strategy of some museums has been to avoid the Lappish Equipage altogether.

Some of the same development can be found in Sámi museums: Symbols that are uniquely Sámi and that set the Sámi apart from majority culture can work as border markers, and the Lappish Equipage is such a border marker. There was a tendency that the first exhibitions at the Sámi museums adopted these symbols but Sámi museums are increasingly trying to broaden the image of Sámi culture and as a result, they try to avoid the use of typical border markers.

On the other hand, a larger number of native museums do employ mannequins in their exhibits; in some cases these are cast from such. The American cultural anthropologist Aaron Glass argues that rather than assuming this to be a simple appropriation of dominant and perhaps even racist paradigms, we need to recognize the "unique discursive contours of this framing" (Glass 2009:77). There can be different motives underlying the need for indigenous people to adopt mannequins as a mode of self-representation. It can be seen as a cultural expression of alterity, as a wish to articulate a specific connection to animals or "nature" or as a strategic accommodation to visitor expectation. Anyhow, it is important to take into consideration indigenous agency, or the agency of Indigenous Nations, as historical and contemporary actors in the contested field of representation.

The Lappish Equipage is still standing both in Sámi museums and in majority museums today, but the Lappish Equipage provides different meanings in these different contexts. The Lappish Equipage in the majority museums is a thing of the past, and is being gradually replaced by other forms of representations, such as photographs. Where the Lappish Equipage can be found in Sámi museums, it is now being self-consciously reframed. The Lappish Equipage is present in the permanent exhibition of Sámi culture and history at the Sámi Collection in Karasjok. Here, the Lappish Equipage is placed directly on the floor, and not on a podium that elevates it from the viewer's standpoint, as is the case in majority museums. Also, there are no barriers between the viewer and the equipage, visitors - if they dare to break the unwritten museum laws of "do not touch!" - can touch the reindeer and the mannequin. There is no illusionary landscape either, nor any dramatic lightning. Here the Lappish Equipage has been stripped down and 
downsized in a way. It has been placed directly on the carpeted floor in front of a concrete wall. In addition, the mannequin has a recognizable face. It has the character of a middle-aged man. Instead of using an illusionary landscape, the Lappish Equipage is placed in front of symbols from Sámi mythology. Sámi mythology frames the whole exhibition, and indeed the whole museum building (Lien \& Nielssen 2011).

The Lappish Equipage has become an iconic picture of a culture. The biography of the Lappish Equipage, which I have barely touched upon in this paper, has the potential to illustrate "some of the mechanics of ethnographic meditation and anthropological knowledge production, the role of recursivity and reiteration in generating iconic cultural objectifications, and the historical entanglement of professional anthropology, public museums, commercial enterprises, and indigenous people" according to Glass (2009:113).

The Lappish Equipage can be seen as a stop sign (Boas), as a close-up (Bal) and as a contact point (Feldman). Even though dioramas or life groups like these are considered by many as an outdated mode of representation, it works. And it works on us in a certain way, on an affective level, a level that pictures, objects and photographs cannot reach so easily. The diorama I call the Lappish Equipage has a chequered history that travels with it, a history of colonialism and anthropometric "science" where humans were classified within a hierarchy of mankind. However and maybe it is precisely because of this history, combined with the diorama's affect-effect, that the Lappish Equipage has a potential to work as a contact point between Sámi history and visitors to the museums. The Lappish Equipage is both a dilemma and a potentially dynamic force in museum exhibitions. Some of its potential lies in showing some of its history. One way of doing this is to reframe or recontextualize the equipage. Instead of throwing the diorama out of the exhibitions, maybe museums should try to consciously reframe the Lappish Equipage?

\section{Notes}

1. When I use the term "Sámi exhibition", I refer to an exhibition where the topic is Sámi culture and history. In so far as the exhibition also represents and describes other cultures, this is done in relation to Sámi culture. A Sámi exhibition can be located in a Sámi museum or in a majority museum.

2. The article draws on the work I did in connection with my Ph.D. thesis, The Aesthetics of Ethnicity: Visual Narratives and Negotiations in Sámi Exhibitions, where I analysed fourteen Sámi exhibitions in six museums in Norway and Sweden (Mathisen 2014). As many as twelve of the fourteen exhibitions I examined had some form of diorama.

3. According to the Norwegian Sámi Council, a Sámi museum should be associated with the Sámi Council and the Sámi Council sets the agenda for the political and academic content. A Sámi museum must be located in a Sámi community and must have the history of Sámi culture and nature as its main topic and focus (Sametingsrådets melding om samiske museer 2004). I use the term "majority museums" for the museums that represent the history and culture of the majority of the population, in this case the ethnic Swedish and Norwegian population.

4. I have borrowed the term "Lappish Equipage" from texts from the nineteenth century. At that time, the Sámi were referred to as "Lapps".

5. In Norway, Sámi culture was exhibited at the Ethnographic Museum in Oslo until 1951, when the Sámi collection was transferred to Norsk Folkemuseum, a national museum for cultural history. In Sweden, Sámi culture was collected 
and exhibited mainly at Nordiska museet, a national museum for cultural history, from the start (1874). Sámi culture was also part of the exhibitions at Etnografiska museet (Museum of Ethnography) and Historiska museet in Stockholm.

6. The first repatriation of Sámi human remains in Norway was made in 1997 when the skulls of Mons Aslaksen Somby and Aslak Jakobsen Hætta, who were executed/decapitated after their participation in the Kautokeino uprising in 1854, were repatriated. Up until 1997 their skulls had been stored in the Schreiner Collection at the Anatomical Institute of the University of Oslo. The Schreiner Collection initially refused to part with the skulls.

\section{INTERNET SOURCES}

"Diorama", Oxford Dictionary, https:// en.oxforddictionaries.com/definition/diorama, (accessed 22 November 2016)

\section{LITERATURE}

Amundsen, Arne Bugge 2011. "National museums in Sápmi." In Peter Aronsson \& Gabriella Elgenius (eds.). Building National Museums in Europe 1750-2010. Conference proceedings from EuNaMus, Bologna 28-30 April 2011. Linköping University Electronic Press, 733-746. http://www. ep.liu.se/ecp/064/031/ecp64031.pdf (accessed 7 April 2017)

Andersson Burnett, Linda 2013. "Selling the Sami. Nordic stereotypes and participatory media in Georgian Britain.” In Jonas Harvard \& Peter Stadius (eds.). Communicating the North. Media Structures and Images in the making of the Nordic Region. Farnham: Ashgate, 171-196.

Baglo, Cathrine 2006. "Samer på ville veger? Om 'levende utstillinger', antropologi og vitenskapelige praksiser." Nordisk Museologi 1, 3-20.
Baglo, Cathrine 2011. "På ville veger? Levende utstillinger av samer i Europa og Amerika." Tromsø: Universitetet i Tromsø, Institutt for arkeologi og sosialantropologi.

Bal, Mieke 2008. "Exhibition as film.” In Robin Ostow (ed.). (Re)visualizing National History. Museums and National Identities in Europe in the New Millennium. Toronto: University of Toronto Press, 15-44.

Eidheim, Harald 1997. "Ethno-political development among the Sámi after World War II. The invention of selfhood." In Harald Gaski (ed.). Sámi Culture in a New Era. Karasjok: Davvi girji, 29-61.

Farnell, Brenda 2011. “Theorizing 'the body' in visual culture." In Marcus Banks \& Jay Ruby (eds.). Made to Be Seen. Perspectives on the History of Visual Anthropology. Chicago/London: University of Chicago Press, 136-158.

Feldman, Jeffrey David 2006. "Contact points. Museums and the lost body problem." In Elizabeth Edwards, Chris Gosden \& Ruth B. Phillips (eds.). Sensible Object.: Colonialism, Museums and Material Culture. Oxford/New York: Berg, 245-267.

Gladstone, Mara \& Janet Catherine Berlo 2011. “The body in the (white) box. Corporeal ethics and museum representation.” In Janet Marstine (ed.). The Routledge Companion to Museum Ethics. Redefining Ethics for the Twenty-First-Century Museum. London/New York: Routledge, 353-378.

Glass, Aaron 2009. "Frozen poses. Hamat'sa dioramas, recursive representation, and the making of a Kwakwaka'waks icon." In Christopher Morton \& Elizabeth Edwards (eds.). Photography, Anthropology and History. Expanding the Frame. Farnham: Ashgate, 89-116.

Haraway, Donna J. 1985. “Teddy bear patriarchy. Taxidermy in the garden of Eden, New York City, 1908-1936." Social Text 11, 20-64.

Henning, Michelle 2006. Museums, Media and Cultural Theory. Maidenhead: Open University Press. 
Hodgson, Dorothy L. 2002. "Introduction. Comparative perspectives on the indigenous rights movements in Africa and in the Americas." American Anthropologist 104:4, 1037-1049.

Kamps, Toby \& Ralph Rugoff 2000. Small World. Dioramas in Contemporary Art. San Diego: Museum of Contemporary Art San Diego.

Lien, Sigrid \& Hilde Nielssen 2011. "Conventional ethnographic display or subversive aesthetics? Historical narratives of the Sámi museum, RiddoDuottarMueat-Sámiid VuorkaDávvirat (RDM-SVD) in Karasjok, Norway." In Dominique Poulot, Felicity Bodenstein \& José María Lanzarote Guiral (eds.). Great Narratives of the Past. Traditions and Revisions in National Museums Conference proceedings from EuNaMus, Paris 29 June-1 July \& 25-26 November 2011. Linköping University Electronic Press, 599-615. http://www.ep.liu.se/ecp/078/037/ ecp12078037.pdf (accessed 7 April 2017)

Lindin, Leif \& Ingvar Svanberg 1990. "Ren dragande en ackja." Västerbotten 2, 110-119.

Mathisen, Silje Opdahl 2014. Etnisitetens estetikk. Visuelle fortellinger og forhandlinger i samiske museumsutstillinger. Oslo: Universitetet i Oslo, Institutt for kulturstudier og orientalske språk.

Mathisen, Stein R. 2004. "Representasjoner av kulturell forskjell. Fortelling, makt og autoritet i utstillinger av samisk kultur". Tidsskrift for kulturforskning 3, 5-25.

Mathisen, Stein R. 2007. "Mr. Bullock's exhibition of Laplanders." Ottar 4, 11-17.

Nodermann-Hedqvist, Maj \& Ernst Manker 1971. "En lapp, kiörandes en oppstoppad rehn. Kommentarer til en kunglig representationsgåva." Livrustkammaren 12:7-8, 192-214.

Olsen, Bjørnar 2000. "Bilder fra fortida?
Representasjoner av samisk kultur i samiske museer." Nordisk Museologi 2, 13-30.

Pareli, Leif, Sissel Ann Mikkelsen \& Anne May Olli 2012. Baastede. Tilbakeføring av samisk kulturarv. Karasjok/Oslo: Norsk Folkemuseum, Sametinget, Kulturhistorisk museum. https://dms-cf-07.dimu. org/file/032waVgq1L3z (accessed 7 April 2017)

Pearce, Susan M. 2008. "William Bullock. Collections and exhibitions at the Egyptian Hall, London, 1816-1825." Journal of the History of Collections 20:1, 17-35.

Sandberg, Mark B. 2003. Living Pictures, Missing Persons. Mannequins, Museums, and Modernity. Princeton: Princeton University Press.

Stordahl, Vigdis 2000. "Et samisk alternativ." Ottar 4, 9-16.

Withson, J. Willard 1996. "Magic in plain sight. The art and science of diorama display." In Mark Dion \& Alexis Rockman (eds.). Concrete Jungle, New York: Juno Books, 201-207.

Wonders, Karen 1993. Habitat Dioramas. Illusions of Wilderness in Museums of Natural History. Uppsala: Uppsala University.

Silje Opdahl Mathisen, Ph.D., Head engineer s.o.mathisen@khm.uio.no

University of Oslo, Museum of Cultural History, Department of Archaeology

Fredriksgate 2

NO-0164 Oslo, Norway 